\title{
Amphetamines and 3,4-methylendioxymetamphetamine (MDMA): evaluation of KIMS (kinetic interaction of microparticles in solution) assay at two cut-off levels
}

\author{
Lucio Marchioro', Flavia Bassetto', Giuliano \\ Dall'Olio" Luciano Tedeschi" Franca Castagna ${ }^{3}$ \\ and Marío Plebanit ${ }^{1 * *}$ \\ 1 Department of Laboratory Mediçine, \\ University-Hospital of Padova, Padova, Italy \\ ${ }^{2}$ Analysis Laboratory, San Bortolo Hospital, Vicenza, \\ italy \\ ${ }^{3}$ Service of Forensic Toxicology and Antidoping, \\ University-Hospital of Padova, Padova, italy
}

\begin{abstract}
Two screening methods for the assay of ampheta. mines and their derivatives have been applied to the same analytiogal instrument for thẹir evaluation. In addition to an assay at a cut-off of $1000 \mu \mathrm{gh}$, a now specifio reagent was evaluated for an ultrassensitive assay of amphetamines and 3,4-methylendioxyme. tamphotamine with a cut-off of $300 \mu \mathrm{g} / \mathrm{l}$. The assay confirmation was performed using high-performance liquid chromatogrophy and gas chromstographyl misss spectrometry techniques. The results were positive for both screening methods, confirming the efficacy of two simultaneous methods with different out-off levels.
\end{abstract}

Keywords: amphotamines; cut-off; gas chromatography/mass spectrometry; kinetic interaction of microparticles in a solution: KIMS; 3,4-methylendioxymetamphetamine: MDMA.

\section{Introduction}

The laboratory plays a fundamental role in the area of substance abuse since it is able to fulfill the needs and the many requests of treatment centers caring for subjects of addiotion, the so-called Ser.T. (Service for Treatment of Substance Abuse) $(1,2)$.

The laboratory activity concerns itself with the searoh for various substances in urine samples, collected during follow-up and before any administration of therapy that might be in progress. To assure anaIytical quality, the system used (both instruments and reagents) must be as much reliable as possible. If, on the one hand, instruments have reached an excellent level of predision, the same cannot be said for the

* Corresponding author: Mario Piobani, Department of taboratory Medicine, University.Hospitsl, Psdova (ftaly). Via Giustiniani, n. 2, 35128 Padova, ltaly

Phone: +390498212780 , Fax: +39049633240

E-mall: mario.plebani@sanita.padovs.it reagents, which sometimes show limitations, independently of the method employed.

In fact while for the assays of opiates, cocaine, cannabinoids and methadone reliable and standardized methods are available, the reagents tsed for the analysis of amphetamines and amphetamine-like sub. stances, in particular Ecstasy 13,4-methylendioxymetamphetamine; MDMAl, have demonstrated noticeable limits due to antibody specificity and reactivity foncentration of the substance which produces an equivalent or higher result in comparison to the cut-off).

The EMIT II PLUS method is not suffioiently accurate in the search for other derivatives of ampheta. mines, methylendioxyamphetamine (MDA) and MDMA, which are the most common components of tablets available on the streets. For this reason, our laboratory evaluated the immunochemical kinetio interaction of microparticles in a solution (KIMS) assay for the measurement of amphetamines fout-off $1000 \mu \mathrm{g} / \mathrm{l})$ and in association with the new ultro-sensitive reagent (cut-off $300 \mu g / 1$ ), specific to MDMA, which was produced specifically as a means of improving the method with a higher out-off value.

\section{Materials and methods}

\section{Sample colsection and analytical instruments}

Urine samples from 70 patients from the Ser.T. of Padur (51) molos, 19 females\}, between the age of 17 and so years, woro collected over a period of 6 months for the clinical monitor ing of the subjecta. Samples were oxamined for the presence of amphotamines and/or other illegal substances. Furthor more, four controls were examined as a para of the program of External Evaluation of Quality Centrol provided by the Service of Foransic Toxicology and Antideping of the Univorsity of Pạdua

For organizstional reasons, urine samples do not atriva at the laboratory on the day of collection. They are preserved at the Ser.T. at $+4^{\prime \prime} \mathrm{C}$ for $\mathbf{2 4}$ hours and then sent to the laborstory for analysis within the 24 hours following their arrival.

All somplos, after boing proceased on the Mego-Marck automated analyzar (DADE-Bohring Ine, flaggow, UK), using the EMII II PLUS immunonatric method (Syva Company DADE-Bohring Inc, Cupertino, CA, USA), ware preserved at $-20^{\circ} \mathrm{C}$ for further analysis. During analysis, as an internal custity control, a "drug-fres" sample and a sample positiva for all substances (Liquid Drug of Abuae Control levelz 1 and 3, Syva Company DADE-Behringl, with concentrations above ossignd

To eliminate doubte concerning the influence of freazing on samples, at the time of use, analysis of amphotamines on the Mega.Merck was repartad uaing the EMTT II PLUS 
Tabte 1 Concentration of ampheptamines that produce an approximazely equivalont result to the threshold lavel of $1000 \mu g / d$ d-motamphetaming (EMIT II PLUS),

\begin{tabular}{|c|c|}
\hline Compound & $\begin{array}{l}\text { Concentrations } \\
\text { logl }\end{array}$ \\
\hline 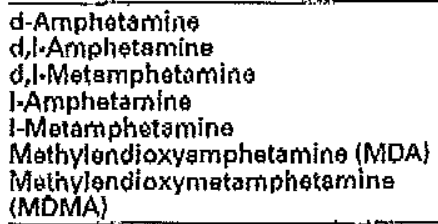 & $\begin{array}{l}1070 \\
1680 \\
1310 \\
7660 \\
2420 \\
2130 \\
9140\end{array}$ \\
\hline
\end{tabular}

Table 2 Concentration of amphetamines that produce an approximately equivalent result to the threshold loval of toọ $\mu g$ th of $\mathrm{d}$-amphatamino (KIMS).

\begin{tabular}{ll}
\hline Compound & Concontration, \\
& $\mu g l$ \\
\hline d, lomphotamina & 1650 \\
Methylendioxyamphotamine (MDA) & 2665 \\
Methylendioxymetampholamino & \\
(MDMA) & 6970 \\
\hline
\end{tabular}

Table 3 Concertrotion of amphetamines that produso an approximately equivalent result to the threshold level of 300 ugh of MDMA (KIMS\}.

\begin{tabular}{|c|c|}
\hline Compound & $\begin{array}{l}\text { Concentration, } \\
\text { |kg/ }\end{array}$ \\
\hline $\begin{array}{l}\text { d.Amphetamine } \\
\text { d, l-Amphatamine } \\
\text { d,l-Metomphotamine } \\
\text { Mothylendioxyamphetamine (NOA) } \\
\text { Methylendioxymetamphotaming } \\
\text { (MDMA) }\end{array}$ & $\begin{array}{r}110 \\
612 \\
252 \\
1392 \\
332\end{array}$ \\
\hline
\end{tabular}

method. Immediately afterwards, the sampleawere analyzed with tho KIMS mathod (Roche Diagnostics, Milan, Italy) for amphetomines and MDMA on a Hitachi 311 analyzer (Rocho Dizgnastica). During each sossion an internat quality control was run with Abuscreen Onkine (Roch Diagnostics) positive and negative controls. After obtsining the resultz, 10 samples were selected for confirmstion analysis with HPLC (HEMEOI, Bio-Had, Milan, ltaly) and with gas chromatography/mass spectrometry (GC/MS) (Hewlatt Packard Con Avondale, CA, USA). The samples were in part chosen based on the amount of urine availablo.

\section{Analytip mothods}

EMIT mothodology EMl' (enzyme multiplisd Immunosssay techniquel ia an immunoenzymatic assay in homogeneous phase used to determine the presence of drugs in biological liquids like urine $(3,4)$. The EMIT II PLUS asaay is the latest generation of EMIT sssays and ytilizes monoclonal antibod. ies, unlike the first EMIT assays that used polyclonal ant]boditos.

The EMIT method is based on competitive binding for antibody sites botwoen the antigen (drug present in the sampls) and the drug marked with glucosen-phosphate dehydrogenase (G6PDH). The anzyme $\mathrm{G} 6 \mathrm{PDH}$ reducs nicotinamide donine dinueleotide $\left(\mathrm{NAD}^{+}\right)$to $\mathrm{NADH}+\mathrm{H}^{+}$with a consequant incregse in absorbance at $340 \mathrm{~nm}$. If the sample is positive, the competition for the antibody will lesve a part of the marked molecules in the solution. The resultant enzymatic activity is therafore dirstly proportional to the concentration of the free markod molecules.
The EMIT II PLUS assay utilizes a calfbration with dmetamphotamine, in agreement with the recommendatiests of the National linstitute on Drug Abuse (NIDA) and equal to the threshold level ackording to the Substance Abuse and Mental Health Sorvices Administration (SAMHSA) (5).

This assay can also identify the following derivatives of amplretamines; d-amphetamine, d,l-amphetamine, d,lmetamphetamine, l-amphefamine, l-metamphotamine, MDA and MDMA (Table 1$)(0-8)$.

The amphetamines can be found in human urine within 3 hours (9) after any type of administration and csn be measured for 24-48 hours following administration of the last dose (5).

The declared (by the manufacturers) sensitivity of the method (limit of detection; LOD), clearly evident by observing the calibration curve, is high: $500 \mu g h$. The declared precision of the mothod is: Precision within a serias: (two levals:

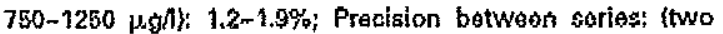
levels: $750-1250 \mu g /$ ): $2.4 \times 4,5 \%$

KIMS method The KIMS technigus (Kinetic interaction of micropurticles in a solution) is based on the kinetic interaction in solution betwean specific antibodias against sub. stances of abuse and microparticles conjugated to the drug and measured as a variation of the extinction of the solution boing examinąd as analyzed by spactrophotomotry at $505 \mathrm{~nm}$ (10). If the drug is absent from the solution, the free antibody binds to the drus conjugated to the microparticles, forming aggregates. In this tase thare is an increase in absorbance.

If o urine sample contains the drug in question, the substance competes for the free antibody with the drug that is conjugated to the microparticles. The antibody that binds the diug is no longer avaliable to form aggregates and the aggregation is thus inhibited. The prosinces of the drug in the urine thes decreases the absorbance ir direct proportion to its concentration in the sample (11).

Even the Abustrean OnLine assay for amphetamines (calibrated based on (damphatominal conforms to the NIDA reoommandation levels.

The assay can identify the following amphetamine deriv. atives: d,l-amphetamine, MDA and MDMA (Toble 2),

The declared (by the manufecturers) analytic sensitivity (LOD) of this method is $11 \mu g /$. The dectared precision of the KIMS method at a cut-off of $1000 \mu \mathrm{g} / \mathrm{l}$ is: Precision within

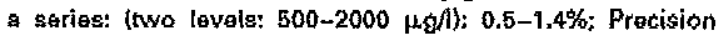
botwoen series: (two leveis: $500-2000 \mu g /)$ : $1.4-3.0 \%$,

in addition to the assay of amphetamines with a cutroff of $1000 \mu \mathrm{g} / \mathrm{l}$, the object of our study wos to ovalliate a now specific reagent for an ultra-sensitlyo assay of amphetar mines and for MDMA (HS Amphetamine/MDMA), which offers the possibility of identifying d-amphetamine, $d_{l}$ amphotomine, dimetamphetamine, MDA and MOMA at very low cencentrations in urine, with a cut-off for MDMA of $300 \mu \mathrm{g} /$ (Tablo 3 ).

The declared analytic sensitivity (LOE) of this method is $23 \mu \mathrm{g} /$. The declared procistion of the KIMS method at a cutoff of $300 \mu \mathrm{g} /$ is: Precision wlthin s sorigat (two levels: 150-450 $($ g/f): 4.7-5.7\%; Precision botweon soriest (two lavis:s: $150-450 \mu g / 1): 6.3-8.2 \%$.

\section{HPLC analygis}

The assays wero carried out uging an HPLC Blo-Rad AEMEDI HS ' Drug Profiling System. The concentrations of several motabolites wore calculatad by using a urinary calibrator with a known concantration of amphetamine, motamphetamine, metladone, codeine and morphine. 
The quatity of the analyois was rogularly checked by means of poriodic tests with CHECK MIX (Bio-Rad\}, containing amphetamine $(2200 \mu g / h$, diazepam, imipramine, mor. phine, hydrosedone and two internal stordards of N.athyl nordiszepam and chorpheniraming. The LODs ape: amphetamine $200 \mu \mathrm{g} / \mathrm{l}$, metamphetamine $150 \mu \mathrm{g} / \mathrm{MOA} 100 \mu \mathrm{g} / \mathrm{t}$ and MDMA $100 \mu g / l$.

The samples consisted of $7.0 \mathrm{ml}$ of urine to which was added $2.0 \mathrm{ml}$ of ammonium acetate $(\mathrm{pH} 8.0)$ containing two internal standards of $\mathrm{N}$.athyl nordiazepam and clorphenira. mine (signalst. The samples were then centrifuged and placed in the autometed analyzer.

The sample is scanned for UV light, and where possibla the apectrum is recorded avery 100 milliseconds (12). The chromatography cycle lasts approximately 17 seconds.

\section{GC/MS analysis}

GCMS combines the resolution power of ges chromatography with the high sensitivity and specificity of mass spectrometry. It is the veference method for toxicology analyais.

The samples were pretreated before injection in several steps: $2 \mathrm{~m}$ l of urine was dilutod to $3 \mathrm{ml}$ using a known concentration of 3,4-methylendioxypropylamphetamine (MDPA) (300 $\mathrm{kg} /$ ); next the samples were brought to $\mathrm{pH} 11 \mathrm{KOH}$ 10 N). The acmples were purified and oxtracted: the $3.0 \mathrm{ml}$ of samples were applied to a separation column (Extreluz 3); aftor $15 \mathrm{~min}, 10 \mathrm{\mu l}$ of acidifiod methanol was added to the collection tube.

Elution followed using $15 \mathrm{ml}$ of othylacetate/hexane and with an additional reduction of the erganic phase by drying. The extract was resuspended (derivatization) with $50[k]$ of trifluere acetate anhydride TFA and $200 \mu$ f of ethylecstate kesping it at $70^{\circ} \mathrm{C}$ for $30 \mathrm{~min}$. The samples were once again dried and resuspended in $100 \mu \mathrm{L}$ of ethylacetate, and then $1 \mu$ of this solution was injected into the GC/MS chromatograph (selected ion monitoring; SiM).

Analysis with GC/MS wore earried out on the HP5890 series 11 gas chromatograph with an HP59t 1 rivalatore censor and KP ULTRA 1 chromatograoh column (crosslinked mothyl siloxane, $12 \mathrm{~m} \times 0.2 \mathrm{~mm} \times 0.33 \mu \mathrm{m}$ film thicken) suitable for the detemination of amphetamine, fenylpropono. lamine, motamphetamino, MOA, MOMA, mathylendioxyethylamphetamine (MDEA) and $N$-methylbenzodioxszolifbutanamine (MBDB), with stanciard MCPA.

Injection-splitless mode The injection temperature was $220^{\circ} \mathrm{C}$; transfer line temperoture Was $280^{\circ} \mathrm{C}$; arrier gas was elio, $0.5 \mathrm{ml} / \mathrm{min}$. The temperature program was $50^{\circ} \mathrm{C}$ for $0.5 \mathrm{~min}$, inereazed to $220^{\circ} \mathrm{C}$ at $16^{\circ} \mathrm{C} / \mathrm{min}$ and to $290^{\circ} \mathrm{C}$ at $40^{\circ} \mathrm{Cl}$ min. The ions used for idantificstion were 140, 118, 9 in and $162 \mathrm{~m} / \mathrm{z}$ for ampliatamines; $\{40,69,203$ and $230 \mathrm{~m} / \mathrm{z}$ for fenylpropanolamine; $154,118,110$ and $245 \mathrm{~m} / \mathrm{z}$ for metamphetamine; $135,105,162$ and $275 \mathrm{~m} / \mathrm{x}$ for MDA; $154,135,110$, 762 and $275 \mathrm{~m} / 2$ for MDA4A; 160, 140, 162, 135 and $303 \mathrm{~m} / \mathrm{z}$ for MDEA; $168,135,176$ and $303 \mathrm{~m} / 2$ for MBDB; and 140 , 162,782 and $317 \mathrm{~m} / \mathrm{z}$ for MDPA. The detection limit was better than $25 \mu \mathrm{g} n$ for all the anslytes.

\section{Results}

Table 4 shows the results obtained with the three screening methods: EMIT II PLUS and KIMS at a cutoff of $1000 \mu \mathrm{g} /$ (KIMS 1000 ) and at a cut-off of 300 ug/l (KIMS 300). All the results described as " $<$ are reported on the basis of the specific values of the declared analytic sensitivity: <500 for EMIT II PLUS, $<11$ tor KIMS at a out-off of $1000 \mu \mathrm{g} / \mathrm{l}$ and $<23 \mathrm{for}$ KIMS at a cut-off of $300 \mu g / 1$. The results reported for the EMIT II PLUS assay are measurements taken affer freezing the samples.

In this Table, there are 70 samples from drug addicts and four samples from external quality controls, selected on the basis of signifient results for amphetamines and derivatives. The choice of these samples was made before receiving the results from the Service of Forensic Toxicology and Antidoping.

\section{KIMS 1000 vs. EMIT II PLUS}

A clinical concordance of $82.4 \%$ could be found from this comparison. Specifically, 59 samples were rec. ognized as negative for both methods $(79.7 \%)$, two samples were positive for both $(2.7 \%)$ and 13 samples were not in agreement. Eleven of these were positive with EMIT II PLUS but negative with KIMS 1000; vice versa, two samples were negative with EMIT II PLUS and positive with KIMS 1000.

All of the above samples were also measured by the KIMS at a cut-off of $300 \mu \mathrm{g} / \mathrm{l}$. The results were compared to both EMIT II PLUS and KIMS $1000 \mu \mathrm{g} /$.

\section{KIMS 300 vs. EMIT II PLUS}

Of the 59 samples that were negative with EMIT II PLUS, 40 had values berween 500 and $1000 \mathrm{Hg} / \mathrm{h}$. Four of these 40 samples were positive with KIMS 300 $(10 \%)$, while 36 were negative $(90 \%)$. Only five of the 13 semples that were positive with EMIT II PLUS were found to be positive with KIMS 300; the remaining eight samples were negative.

\section{KIMS 300 va. KIMS 1000}

Comparison samples with concentrations between the cutroff values for the two methods $1300-1000$ $\mu g l)$ were selented. All six samples were positive with KIMS 300 . Four samples found to be positive with KIMS 1000 were also positive with KIMS 300. The results of the 10 samples selected for confirmation analysis with HFLC and GC/MS are reported in Table 5. Four control samples were also analyzed for a total of 14 samples. Seven of these were positive with $\mathrm{GCJ}$ MS.

\section{EMIT II PLUS vs. GC/MS}

The olinical concordance between results obtained with EMIT II PLUS and the reference method (GC/MS) was $64.3 \%$. In particular, of the seven samples found to be positive with the reference mothod (GC/MS), only three semples were positive (true positives; sensitivity $42,8 \%$ ) with EMIT II PLUS (four samples were false negatives), while, with respect to the seven negative samples, six were negative with EMIT II PLUS (true negatives; specificity $85.7 \%$ ), and one was positive (false positive). 
Table 4 Results $(\mu g n)$ obtained with the three immunoenzymatic methodologies.

\begin{tabular}{|c|c|c|c|}
\hline Semple & $\begin{array}{l}\text { EAMIT } 1000 \\
\mu, A l\end{array}$ & KIMS 1000 & $\begin{array}{l}\text { KIMS } 300 \\
\mu g h\end{array}$ \\
\hline 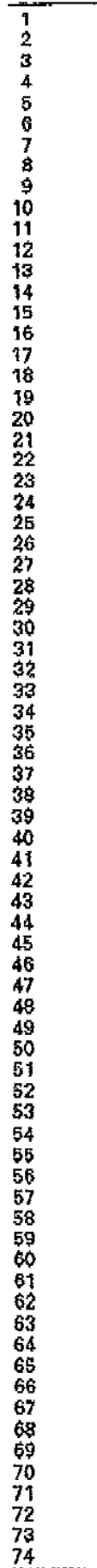 & 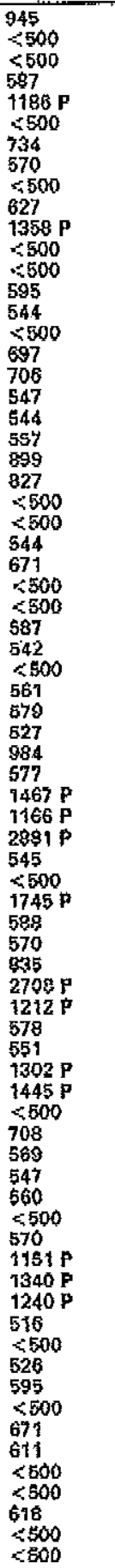 & 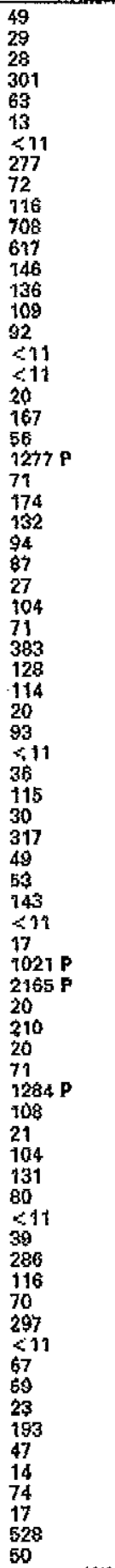 & 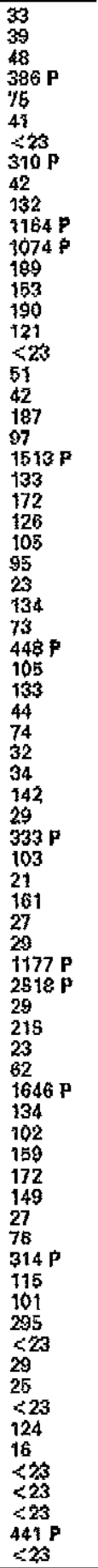 \\
\hline
\end{tabular}

Lefter f. perar the number, indicates positive rosults for the specific astaty.

\section{KIMS 1000 vE. GC/MS}

The clinical concordance between results obtained with KIMS $1000 \mu g /$ and the reference method $16 \mathrm{Cl} /$ MS) wes $7 \uparrow .4 \%$. In this case as well, of the soven sam. ples found positive with the reference method (GC) MS), orly three (true positives; sensitivity $42.8 \%$ ) Ware positive with KIMS 1000 ugf (four samples were therefore false negativest, while, for negative samples (true negatives) the concordance was $100 \%$ (specificity $100 \%)$.

\section{KIMS 300 vs, GC/MS}

The olinical concordanoe between results obtained with KiM\$ $300 \mu \mathrm{g} / \mathrm{l}$ and the reference method $[\mathrm{GC}$ l MS) was $78.6 \%$. In particular, of the seven positive samples with GC/MS, six were found positive itrue positives; sensitivity $85.7 \%$ ), therefore, one sample was a false negative; among the seven semples found negative with GC/MS, five were negative (true negatives; specificity $71.4 \%$ ) and thus two samples were false positives. Howgver, for the two false positive semples with KIMS $300 \mu g / h$, the HPLC-REMEDI method detected probsble drug interference. In adoition, it should be noted that MDEA (sometimes present in pills from illegal sources) in the control sample Contr.1/01 and detected by GC/MS was not recognzed by KIMS $300 \mu g /$ (Tahle 6 ). Table 7 shows the summary of the serisitivity and spoaificity dota.

\section{Discussion and conclusions}

In the panorama of substance abuse, synthetic drugs, in particular amphetamines, are the second most widely used illegal substances in the Furopean Union $(1-9 \%$ of the adult population and up to $13 \%$ of adolescents have tried them) (13), second only to cannabinoids.

The epidemiological research on the use of Ecstasy in Europe is soerce and fragmentary: the estimates are $0.5-3 \%$ of the adult population and $1-9 \%$ of adolescents between the age of 15-16 years. In particular, in the United Kingdom it is estimated that approximately 750,000 pills of Ecstasy are consumed on any given weekend and that more than a million people have tried the drug at least once (14). A French study claims that the age of Ecstasy users varies from 19 to 25 years, while other amphetamines are primarily used among the 24-30 yoars oid age group (15).

The data in Italy, calculated by the President of the Italian Council, Ministry for Social Affairs, concern $50,000-80,000$ youths who use the drug on a weekly basis at danoing parties/discotheques. Their age ranges from 15 to 25 years. (1). Moreovei, study of the general population and of students indicates a modest Increase in the use of both drugs. Deaths due to synthetic drug use are rare, and rarely do individuals seek detoxification treatment. However, Scandinavian countries, Belgium and Enigland have more frequent problems caused by amphetamines, especially among chronic and intravenous users (1). The results in a Dutch study indicate that heavy use of MDMA is associated with neurotoxic effects on serotonin neyrons and that women might be more susceptible than men (16).

The aim of every mediogl laboratory is to improve its activity, so as to guarantee the reliability of the 
Table 5 Resulto obteined with HPLC-REMEDI and GC/MS mothodologies.

\begin{tabular}{|c|c|c|c|c|c|c|}
\hline Sample & $\begin{array}{l}\text { EMIT II PLUS } \\
\text { Cut-off } \\
1000 \mu g / 1\end{array}$ & $\begin{array}{l}\text { Kivs } \\
\text { Cut-off } \\
1000 \mu g / 1\end{array}$ & $\begin{array}{l}\text { KINAS } \\
\text { Cutoff } \\
300 \mu g y t\end{array}$ & HPLC-REMMEDI & $\begin{array}{l}\text { HPLC-REMEDI } \\
\text { conment }\end{array}$ & $\begin{array}{l}\mathrm{GC} / \mathrm{MS}^{2} \\
\mu \mathrm{g} / l\end{array}$ \\
\hline 1 & 945 & 49 & 33 & Negative & \multirow{5}{*}{$\begin{array}{l}\text { Drug?? Interference } \\
\text { Drug?? Interference }\end{array}$} & Nogative \\
\hline 4 & 587 & 301 & $386 P$ & Anfotamina? & & Negetive \\
\hline 5 & $1186 \mathrm{P}$ & 63 & 75 & Amfetamine neg. & & Nogative \\
\hline 8 & 570 & 277 & $310 \mathrm{P}$ & Amfetamine? & & Negativo \\
\hline 13 & $<500$ & 146 & 189 & Amfotamine neg. & & Negative \\
\hline 22 & 899 & $1277 P$ & $1513 \mathrm{P}$ & $\begin{array}{l}\text { MDA pos, } \\
\text { MOMA? }\end{array}$ & \multirow[t]{5}{*}{$\begin{array}{l}\text { Efadrine ard } \\
\text { MDMA }\end{array}$} & $\begin{array}{l}\text { MDA } 769 \\
\text { MDAA } 2853\end{array}$ \\
\hline 30 & 587 & 77 & 73 & Amfetamine nog. & & Nogative \\
\hline 40 & $2881 \mathrm{P}$ & 317 & $333 \mathrm{P}$ & MDA, MUMA & & MDA 414 \\
\hline 46 & 835 & $1021 \mathrm{P}$ & $7777 \mathrm{P}$ & $\mathrm{MDA}_{2}$ MDMA & & $\begin{array}{l}\text { MOMA } 1276 \\
\text { MDA } 560\end{array}$ \\
\hline 47 & $2708 \mathrm{P}$ & $2165 P$ & $25+6 \mathrm{P}$ & $M D A, M D M A$ & & $\begin{array}{l}\text { MDMA } 6329 \\
\text { MDA } 3687 \\
\text { MDMA } 8533 \\
\end{array}$ \\
\hline
\end{tabular}

Table 6 Results obtained for control samples with GC/MS methodology.

\begin{tabular}{|c|c|c|c|c|}
\hline Samplo & $\begin{array}{l}\text { EMIT II PL.US } \\
\text { Cut-off } 1000 \mathrm{\mu g} / \mathrm{l}\end{array}$ & $\begin{array}{l}\text { KIMS } \\
\text { Cutroff } 1000 \mu g / 1\end{array}$ & $\begin{array}{l}\text { KMS } \\
\text { Cut-off } 300 \mathrm{kg/h}\end{array}$ & GCMMS, $\# 9$ \\
\hline $\begin{array}{l}11 \\
\text { Contr. } 4 / 00\end{array}$ & $1750 \mathrm{P}$ & 708 & $1164 P$ & MOMA 1275 \\
\hline $\begin{array}{l}12 \\
\text { Contr. } 5100\end{array}$ & $<500$ & 677 & $1075 \mathrm{P}$ & MDMA 523 \\
\hline 63 & 816 & 297 & 295 & $\begin{array}{l}\text { MDEA } 12229 \\
\text { MDA } 240\end{array}$ \\
\hline $\begin{array}{l}64 \\
\text { Contr. A/01 }\end{array}$ & $<600$ & $\$ 17$ & $<23$ & Nagative \\
\hline
\end{tabular}

Letter $P$, near the number, indicates positive results for the specific sssay.

Table 7 Summary of sensitivity and specificity data of EMIT II PLUS, KIMS 1000 and $\$ 00 \mu$ obtained using $G C M M S$ os a reference methọd,

\begin{tabular}{|c|c|c|}
\hline Immunologitat asaay & $\begin{array}{l}\text { True positives } \\
\text { Sensitivity, \% }\end{array}$ & $\begin{array}{l}\text { True nagatives } \\
\text { Sposifiéty, } \%\end{array}$ \\
\hline 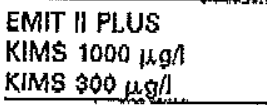 & $\begin{array}{l}42.8 \\
42.8 \\
65.7 \\
\end{array}$ & $\begin{array}{c}85.7 \\
100 \\
71.4 \\
\end{array}$ \\
\hline
\end{tabular}

data it produces. For this reason every laboratory must constantly seek the most suitable methods. Considering the continuing incresse in the use of illegal substances, including amphetamines and derivatives (MDMA), there is a disorepancy in the higher mumber of the police finds on the ilfegal market with respect to the number of blological samples found to be positive (13). This could be due to the lack of adequate immunometric assays to analyze samplas for MDMA and other derivatives of amphotamine, thus resulting in false negatives.

The enzyme-based EMIT II PLUS assay, specific to amphetamine and motamphetamine, is not sufficiently accurate in assaying othor derivatives of amphetamines, MDA and MDMA, the most common components of illegal pills.

In particular, MDMA must be present in the urine at concentrations of approximately $\$ 000 \mathrm{ug} / \mathrm{l}$ in order to produce a positive result with a cut-off of $9000 \mu \mathrm{g} / \mathrm{h}$. These are relatively high concentrations that are found in urine only with particularly favorable para. meters, such as a sample collection close to the time of substance administration, the hydration state of the subject, the concentration of the ingredient in the pills, etc.

This without sny doubt represents a fimitation, since using only screening assays offects a risk of missing a number of positive somples (high number of false negatives due to the difficult conditions necessary for $100 \%$ cross-reactivity) (2). The resulting clinical concordance $(82,4 \%)$ between the two soreening methods (EMIT II PLUS and KIMS 1000) is not sutficient, at least in our opinion. The production of high-affinity antibodies is one of the greatest prob. lems in developing assays, and is made even more difficult by the constant introduction of new synthetic substances. The use of a supplemental screening reagent (KIMS 300), which is specific to amphetamine and MDMA, is certainly valuable even if in this study it was assessed against an assay with a different method (EMIT If PLUS). Taking into account the study population (drug addiots who present to Ser.T.) and the low number of samples tested with the refarence method, the analysis of the results leads to certain considerations. The clinical laboratory, with the screening methods, is able to provide only prefiminary data which require further confirmation with HPLC or GC/MS assays for all positive results (as well as for suspocted positives).

It would be useful to have the most specific assay methods available, which oan discern true negatives, beoause positive results should always be confirmed. 
The results of this study are in favor of the use of the KIMS method and emphasize the effectiveness of the simultaneous use of two methods with different cut-off lovets.

Without confirmation by other methods (HPLC o GC/MS), the method at $300 \mu g / l$ could well represent a valid improvement of the test at $1000 \mu \mathrm{g} /$. Yet, the use of the KIMS test at the lower cut-off atone is not recommended because the use of a lewer cut-off would increase the number of positive samples, thus increasing the number of verification assays and therefore the costs involved.

Our study, morepover, confirms that the GCMS method must still be considered the reference method, mainly in cases where results might have legal value.

\section{Acknowiedgements}

We wish to thank Mrs. Silvia Ponchia for her excellent technical assistance.

\section{References}

3. Magliocetti N. Rilevazione attivita nel settore delle tossicodipendenze, anno 1996. Bollettino per le Fapmotodjpendenze o L'Alcolismo, 1999:3.

2. Marchíloro L, Pezzuti P, Fiore C, Valentini G, Biliotti G, Riz. zotti $P$. Abuse of illicit substances in two middle-north ital. isn areas: study of provalence using the same anulytical methodology. Riv Med Lab-JLM, 2001;2:12-8.

3. Rubenstain KE. Homoganeous enzyme immunoasay today. Scand J Inmunol 1978;8:suppl7:57-60.
4. Brattin WJ, Sunshine J. Immunological assays for drugs in biological samples. Am J Mod Teohnol 1973;39:223-5.

5. Rockville MD, National Inslitute on Drug Abuse (NIDA). Department of Health and Human Services. NIDA research monograph 1986:73.

6. Handbook of non-prescription drugs. Washington, DC: Americen Pharmaceuticals Association, 1987:142pp.

7. Basatt $R C$, Cravey RH. Disposition of toxit drug? and chemicals in man, 3rd ed. Chicago, IL: Year Book Medi. col Publishers, Ino, 7989:320,628,738.

8. Diem K, Lentrer C. Geigy Scientific Tables, 7th od. Ardaley, NY: Goigy Pharmaceuticals, 1997:668pp.

9. AHFS Drug information ' 87 . American Sociaty of Hos. pital Pharmeceutical, inc., 1987:1105-7.

10. Adler FL, Liu CT. Detection of morphine by hemagglutination-inhibition. 5 Immunol 1971;706:7684-5.

11. Rouse S, Motter K, McNally A, Steppe T, Ward C. An Abuscreen Online immunoassay for the detection of amphetsmine in urine on the COBAS MIRA Automated Analyzer [abstract]. Clin Chem 1991;37:995.

72. Cangiano G, De Rosa $G$, D'Amora $M$, Fuscone A, Garofono $R$, Marguccio $E$, ot al. Cromstografia liquida (HPLC) applicate alla determinazione delle droghe d'abuso urinario di campioni provenienti dai Ser.T, Bio-fiad 2000:2-5.

13. Lora Temayo C. Analytical strategies for MDMA analysis (annud report). Instituto Nacionel de roxicologia, Mi. risterio do Justicia, Madrid, Spain, 2000.

14. Cook A. Ecstasy (MDMA): alarting users to the dangers. Nurs Times 1991;1:32-33.

15. San Morco Jl, Lagior G, Observation des produits psychotropes illicites ou détournez de leur utilisation medJesmentouse: ainq ans de surveillances des produits consommes par les toxicomanos a Marsoille. Therapie $1996 ; 51 ; 586-98$.

16. Reneman L, Booij J, De Bruin K, Reitsma JB, De Wolf FA, Gunning WB. Effects of dose, tox, and longrterm abstention from $u s \theta$ on toxic affecte of MDMA (Ecstasy) on brein serotonin neurons. Lancet 2003;358:1864.

Raceived November 11, 2003, accepted February 26, 2004 